\title{
PENGARUH EKSTRAK DAUN PEDADA (Sonneratia alba) TERHADAP MUTU PASCA PANEN UDANG API-API (Metapenaeus monoceros)
}

\author{
Samsu Rizal ${ }^{1 *}$, Andi Noor Asiki ${ }^{1}$, Gina Saptiani ${ }^{1}$ \\ Program Studi Teknologi Hasil Perikanan, Fakultas Perikanan dan Ilmu Kelautan, Universitas \\ Mulawarman, Samarinda \\ *email korespondensi: samsurizal@gmail.com
}

\begin{abstract}
ABSTRAK
Udang menjadi komoditi unggulan yang diperdagangkan di pasar lokal maupun internasional. Proses kemunduran mutu udang dapat disebabkan oleh adanya reaksi autolisis. Permasalahan tersebut merupakan dasar pemikiran untuk mencari alternatif pengawet alami yang tidak berbahaya dan mudah diperoleh yaitu menggunakan daun pedada $(S$. $a / b a)$. Penelitian ini bertujuan untuk mengetahui pengaruh ekstrak daun pedada ( $S$. alba) terhadap mutu pasca panen udang api-api dan mengetahui konsentrasi terbaik dalam menghambat pertumbuhan bakteri selama penyimpanan dingin $\left(5^{\circ} \mathrm{C}\right)$. Parameter uji yang diamati yaitu TPC, pH dan uji organoleptik. Penelitian ini menggunakan Rancangan Acak Lengkap (RAL) dengan 5 perlakuan dan 3 ulangan. Perlakuan terdiri dari P1 (ekstrak air laut $+S$. alba 800 ppm); P2 (ekstrak air laut + S. alba 1200 ppm); P3 (ekstrak air tawar + S. alba 800 ppm); P4 (ekstrak air tawar + S. alba 1200 ppm); dan P5 (kontrol/tanpa ekstrak). Hasil penelitian menunjukkan bahwa perendaman udang api-api dalam ekstrak daun pedada tidak memberikan pengaruh terhadap nilai TPC dan $\mathrm{pH}$ selama penyimpanan dingin, namun berpengaruh terhadap uji organoleptik spesifikasi kenampakan, bau dan tekstur udang. Ekstrak daun pedada dengan pelarut air laut $1200 \mathrm{ppm}$ selama penyimpanan dingin $\left(5^{\circ} \mathrm{C}\right)$ memperoleh hasil terbaik dengan nilai TPC yaitu 2,88 log cfu/g, nilai pH 7,12 dan nilai organoleptik (kenampakan 7,3, bau 7,3 dan tekstur 7,3).
\end{abstract}

Kata Kunci : Ekstrak daun pepada; Metapenaeus monoceros; Sonneratia alba; Udang api-api

\section{ABSTRACT}

Shrimp is a leading commodity traded in local and international markets. The process of deterioration of shrimp quality can be caused by an autolysis reaction. This problem is the rationale for looking for an alternative natural preservative that is harmless and easy to obtain, namely using pedada (S. alba) leaves. This study aimed to determine the effect of pedada leaf extract (S. alba) on the postharvest quality of fire shrimp and to determine the best concentration in inhibiting bacterial growth during cold storage (5oC). The test parameters observed were TPC, $p H$, and organoleptic tests. This study used a completely randomized design (CRD) with 5 treatments and 3 replications. The treatments consisted of P1 (seawater extract +800 ppm S. alba); P2 (seawater extract + S. alba 1200 ppm); P3 (freshwater extract + S. alba 800 ppm); P4 (freshwater extract + S. alba 1200 ppm); and P5 (control/without extract). The results showed that the immersion of fire shrimp in pedada leaf extract did not affect the TPC and $\mathrm{pH}$ values during cold storage, but did affect the organoleptic test for the

36 Pengaruh Ekstrak Daun Pedada (Sonneratia Alba) Terhadap Mutu Pasca Panen Udang Api-Api (Metapenaeus Monoceros)/ Samsu Rizal, Andi Noor Asiki, Gina Saptiani

Journal of Agritechnology and Food Processing

Volume 1, No. 1, 2021

Jl. K. H. Ahmad Dahlan No. 1, Pagesangan-Mataram, Indonesia 
appearance, smell, and texture specifications of the shrimp. Pedada leaf extract with 1200 ppm seawater as a solvent during cold storage $\left(5^{\circ} \mathrm{C}\right)$ obtained the best results with a TPC value of $2.88 \log \mathrm{cfu} / \mathrm{g}$, a pH value of 7.12, and an organoleptic value (appearance 7.3 , odor 7.3 and texture 7,3 ).

Keywords: Fire shrimp; Metapenaeus monoceros; Pepada leaves extract; Sonneratia alba

\section{PENDAHULUAN}

Indonesia merupakan negara kepulauan yang memiliki kekayaan sumber daya alam terutama yang berasal dari perairan, seperti ikan, udang dan kepiting yang menjadi komoditi unggulan untuk diperdagangkan di pasar lokal maupun internasional. Dari beberapa komoditi perikanan, udang menjadi salah satu produk yang banyak dibudidayakan baik menggunakan kolam buatan maupun yang menggunakan tambak tradisional. Hasil budidaya udang yang berlimpah mengharuskan perlu adanya penanganan yang baik agar udang tetap terjaga kesegarannya, mengingat bahwa udang memiliki kandungan nutrisi yang baik seperti asam lemak (omega-3 dan omega-6) kitosan, mineral, lipit, karotenoid, vitamin, serta protein (Ngginak et al., 2013), dimana sumber-sumber nutrisi tersebut sangat baik bagi pertumbuhan mikroba pembusuk terutama bakteri yang dapat mempengaruhi mutu udang.

Proses kemunduran mutu udang dapat disebabkan oleh adanya reaksi autolisis yaitu dapat dipengaruhi oleh adanya aktivitas enzim, aktivitas bakteri, dan reaksi kimiawi pada saat penyimpanan (Suwetja, 2011). Bakteri yang terdapat pada udang yaitu Achromobacter, Alcalegenes, Staphylococcus aureus, Salmonella dan Pseudomonas yang merupakan bakteri pembusuk pada udang (Hadiwiyoto, 1993). Keberadaan mikroba pada udang ini tentu akan mengakibatkan kerusakan dan menurunnya mutu udang sehingga perlu penanganan yang tepat, diantaranya dengan menggunakan es dan bahan pengawet kimia. Bahan pengawet yang sering dijumpai di lapangan adalah formalin yang berfungsi untuk mempertahankan kesegaran hasil tangkapan. Namun, penggunaan pengawet formalin dapat beresiko menimbulkan gangguan kesehatan bagi yang mengkonsumsinya.

Permasalahan tersebut merupakan dasar pemikiran untuk mencari alternatif pengawet alami yang tidak berbahaya jika dikonsumsi dan mudah diperoleh. Salah satu alternatif yang dapat digunakan sebagai pengawet alami adalah tumbuhan mangrove terutama anggota Genus Sonneratia yang telah dilaporkan mengandung senyawa bioaktif yang bersifat antimikroba. Sonneratia alba bersifat antibakterial terhadap E. coli, S aureus, V. haveyi, A. hydrophila dan anti fungal terhadap Saprolegnia sp. (Saptiani et al., 2018). Pemanfaatan ekstrak daun pedada (S. $a l b a$ ) sebagai pengawet alami untuk mempertahankan kesegaran mutu udang belum banyak dilakukan. Oleh karena itu, perlu dilakukan penelitian penggunaan ekstrak daun pedada ( $S$.

37 Pengaruh Ekstrak Daun Pedada (Sonneratia Alba) Terhadap Mutu Pasca Panen Udang Api-Api (Metapenaeus Monoceros)/ Samsu Rizal, Andi Noor Asiki, Gina Saptiani

Journal of Agritechnology and Food Processing Volume 1, No. 1, 2021

J1. K. H. Ahmad Dahlan No. 1, Pagesangan-Mataram, Indonesia 
alba) dengan pelarut air laut dan air tawar sebagai bahan pengawet alami untuk menghambat pertumbuhan bakteri pada udang api-api selama penyimpanan dingin $\left(5^{\circ} \mathrm{C}\right)$.

\section{METODE PENELITIAN}

Penelitian ini dilakukan dalam 2 tahap yaitu tahap persiapan meliputi pembuatan ekstrak daun pedada (S. alba) dan perendaman udang dalam ekstrak. Tahapan penelitian meliputi sterilisasi alat, pembuatan media, sterilisasi bahan, persiapan sampel, pengeceran ekstrak daun pedada (S. alba), perendaman udang dalam larutan ekstrak, penirisan, penyimpanan udang, dan pengujian sampel.

Penelitian ini menggunakan Rancangan Acak Lengkap (RAL) dengan 5 perlakuan dan 3 ulangan yaitu P1 (ekstrak air laut + S. alba 800 ppm); P2 (ekstrak air laut + S. alba 1200 ppm); P3 (ekstrak air tawar + S. alba 800 ppm); P4 (ekstrak air tawar + S. alba 1200 ppm); dan P5 (kontrol/tanpa ekstrak). Parameter uji yang diamati dalam penelitian ini, yaitu TPC (Total Plate Count) , pH dan uji organoleptik.

\section{HASIL DAN PEMBAHASAN}

\section{Jumlah bakteri udang dengan metode (TPC)}

Nilai rata-rata TPC pada daging udang api-api selama penyimpanan dingin $\left(5^{\circ} \mathrm{C}\right)$ dapat dilihat pada Gambar 1.

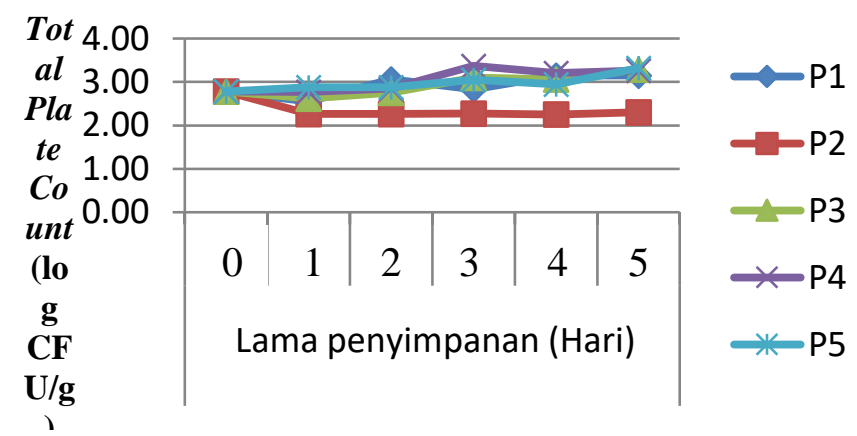

Keterangan:

Gambar 1. Nilai TPC pada udang api-api selama penyimpanan dingin $\left(5^{\circ} \mathrm{C}\right)$

$\mathrm{P} 1=$ Ekstrak air laut + S. alba $800 \mathrm{ppm}$

$\mathrm{P} 2=$ Ekstrak air laut + S. alba 1200 ppm

P3= Ekstrak air tawar + S. alba 800 ppm

$\mathrm{P} 4=$ Ekstrak air tawar + S. alba 1200 ppm

$\mathrm{P} 5=$ Kontrol

Analisis keragaman (Anova) memperlihatkan bahwa tidak terdapat beda nyata $(P>0,05)$ antar perlakuan yang diberikan sehingga tidak dilakukan uji lanjut. Hasil uji TPC daging udang api-api pada hari ke-0 (sebelum perlakuan) sebesar 2,78 log cfu/g. Pengamatan hari ke-1

38 Pengaruh Ekstrak Daun Pedada (Sonneratia Alba) Terhadap Mutu Pasca Panen Udang Api-Api (Metapenaeus Monoceros)/ Samsu Rizal, Andi Noor Asiki, Gina Saptiani

Journal of Agritechnology and Food Processing

Volume 1, No. 1, 2021

Jl. K. H. Ahmad Dahlan No. 1, Pagesangan-Mataram, Indonesia 
berkisar 2,55-3,15 log cfu/g, hari ke-2 berkisar 2,25-2,30 log cfu/g, hari ke-3 berkisar 2,62-3,29 log cfu/g, hari ke-4 berkisar 2,77-3,37 log cfu/g, dan hari ke-5 berkisar 2,88-3,32 log cfu/g. Nilai TPC udang api-api selama penyimpanan suhu dingin $\left(5^{\circ} \mathrm{C}\right)$ lebih rendah dibandingkan standar SNI untuk jenis krustase yaitu $5 \times 10^{5} \mathrm{cfu} / \mathrm{g}$ atau sama dengan $5,70 \log \mathrm{cfu} / \mathrm{g}$ (BSN, 2009). Hal ini sejalan hasil penelitian Kusumadewi (2014) bahwa ekstrak S. alba mengandung metabolit sekunder yaitu senyawa alkaloid, flavonoid dan tanin yang memiliki sifat merusak dinding sel bakteri sehingga mampu menghambat pertumbuhan bakteri pada udang seperti $V$. alginolyticus, Alcaligenes, Vibro vulnificus, V. parahaemolyticus, V. harveyi, Vibrio fischeri dan A. hydrophila.

Penggunaan ekstrak daun pedada dengan pelarut air laut dalam penelitian ini menunjukkan bahwa semakin tinggi konsentrasi ekstrak yang digunakan maka semakin efektif dalam menghambat pertumbuhan bakteri pada udang pasca penen. Santi et al. (2017) menyatakan bahwa ekstrak dengan pelarut air laut Avicennia marina 0,05\% lebih efektif dalam menghambat pertumbuhan V.harveyi pada benur udang windu (Peneaus monodon) dibandingkan media dengan pelarut air laut daun Avicennia marina 0,01\%. Menurut Saptiani et al., (2018), keunggulan dari penggunaan pelarut air ini adalah murah dan mudah digunakan.

Faktor yang mempengaruhi pertumbuhan bakteri disebabkan oleh suhu dan lama waktu penyimpanan. Suhu selama penyimpanan 5 hari dalam penelitian ini yaitu $5^{\circ} \mathrm{C}$, diduga belum menunjukkan pengaruh yang signifikan terhadap pertumbuhan mikroba. Hal ini sejalan dengan penelitian Nikoo et al. (2019) yang menunjukkan bahwa selama penyimpanan pada suhu 4ㅇ C terjadi peningkatam nilai mikroba. Menurut Susanto et al. (2011), penggunaan suhu rendah dan perendaman dalam larutan bahan alami dapat mengambat pertumbuhan bakteri tetapi tidak menghentikan laju pertumbuhan bakteri. Hasil penelitian Husni et al. (2014) menyatakan bahwa fillet nila merah yang disimpan pada suhu dingin dengan perlakuan ekstrak Sargassum sp. $1 \%$ berdasarkan total kandungan bakteri masih layak dikonsumsi sampai hari ke-12. Nilai TPC pada udang api-api selama penyimpanan 5 hari pada suhu dingin $\left(5^{\circ} \mathrm{C}\right)$ lebih rendah dibandingkan dengan standar SNI sehingga udang masih bisa diterima dan layak dikonsumsi.

\section{Nilai pH}

Nilai rerata $\mathrm{pH}$ daging udang selama penyimpanan dingin $\left(5^{\circ} \mathrm{C}\right)$ dapat dilihat pada Gambar

2.

39 Pengaruh Ekstrak Daun Pedada (Sonneratia Alba) Terhadap Mutu Pasca Panen Udang Api-Api (Metapenaeus Monoceros)/ Samsu Rizal, Andi Noor Asiki, Gina Saptiani

Journal of Agritechnology and Food Processing Volume 1, No. 1, 2021

Jl. K. H. Ahmad Dahlan No. 1, Pagesangan-Mataram, Indonesia 


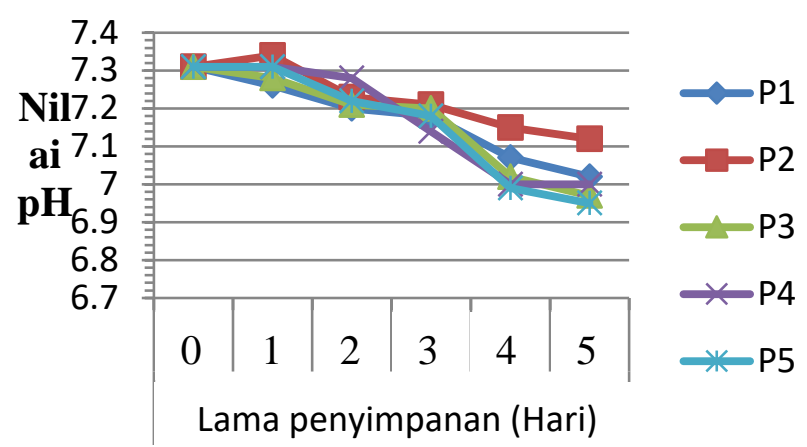

Keterangan:

Gambar 2. Nilai rata-rata pH daging udang api-api selama penyimpanan dingin (5ㄷ)

$\mathrm{P} 1=$ Ekstrak air laut + S. alba $800 \mathrm{ppm}$

$\mathrm{P} 2=$ Ekstrak air laut + S. alba $1200 \mathrm{ppm}$

P3= Ekstrak air tawar + S. alba 800 ppm

P4= Ekstrak air tawar + S. alba 1200 ppm

P5= Kontrol

Berdasarkan analisis keragaman (Anova) bahwa perlakuan yang diberikan tidak berbeda nyata $(P>0,05)$ terhadap nilai $\mathrm{pH}$ daging udang sehingga tidak dilakukan uji lanjut. Hasil pengamatan memperlihatkan daging udang api-api dengan perlakuan ekstrak memiliki nilai rarata $\mathrm{pH}$ yang tinggi dibandingkan tanpa menggunakan ekstrak $S$. alba. Hal ini diduga senyawa bioaktif yang terkandung pada ekstrak daun pedada mampu menghambat pertumbuhan bakteri pembusuk, sehingga perombakan asam amino menjadi basa nitrogen terhambat dan mengakibatkan nilai pH menjadi lebih tinggi. Menurut Riyanto et al. (2006), nilai pH berhubungan dengan aktivitas bakteri dan enzim yang secara alami sudah ada. Kondisi ini menyebabkan peningkatan $\mathrm{pH}$ yang mengakibatkan pembentukan ammonia TMA dan turunannya. Selain pengaruh ekstrak, suhu dan lama waktu penyimpanan juga dapat menghambat pertumbuhan bakteri tetapi tidak mampu menghentikan laju pertumbuhan bakteri. Munandar et al. (2009) menyatakan bahwa suhu rendah dapat menyebabkan aktivas enzim yang terdapat pada daging ikan menjadi terhambat sehingga kemunduran mutunya berjalan lebih lambat, semakin rendah suhu yang digunakan maka aktivitas enzim semakin terhambat, sehingga akumulasi asam laktat dan proses penguraian protein menjadi senyawasenyawa yang bersifat basa oleh bakteri juga terhambat dan peningkatan $\mathrm{pH}$ ikan berlangsung lebih lama.

Hasil pengamatan menunjukkan bahwa dengan nilai pH tertinggi pada perlakuan P2 (air laut 1200 dan ekstrak S. alba), yaitu 7,12 dan terendah pada P3, yaitu 6,95. Penurunan nilai pH daging udang api-api yang direndam dengan ekstrak daun S. alba lebih lambat dibandingkan dengan tanpa penggunaan ekstrak. Nilai $\mathrm{pH}$ selama penyimpanan dingin suhu $5^{\circ} \mathrm{C}$ secara statistik menunjukkan tidak berpengaruh nyata, dibandingkan SNI nilai pH ikan atau udang

40 Pengaruh Ekstrak Daun Pedada (Sonneratia Alba) Terhadap Mutu Pasca Panen Udang Api-Api (Metapenaeus Monoceros)/ Samsu Rizal, Andi Noor Asiki, Gina Saptiani

Journal of Agritechnology and Food Processing

Volume 1, No. 1, 2021

Jl. K. H. Ahmad Dahlan No. 1, Pagesangan-Mataram, Indonesia 
segar. Menurut Shamsad (1990) produk udang memilih kualitas yang baik dan dapat diterima pada $\mathrm{pH} 7,5$. Hal ini diperkuat oleh hasil penelitian Mursida (2015) umumnya udang yang masih hidup mempunyai nilai $\mathrm{pH}$ netral yaitu 7-7,5.

\section{UJi Organoleptik}

Uji organoleptik merupakan salah satu faktor untuk menilai kemunduran mutu hasil perikanan. Uji organoleptik diamati meliputi ssepesifikasi kenampakan, bau dan tekstur.

\section{1) Kenampakan}

Nilai kenampakan udang selama penyimpanan suhu $5^{\circ} \mathrm{C}$ dapat dilihat pada Gambar 3.

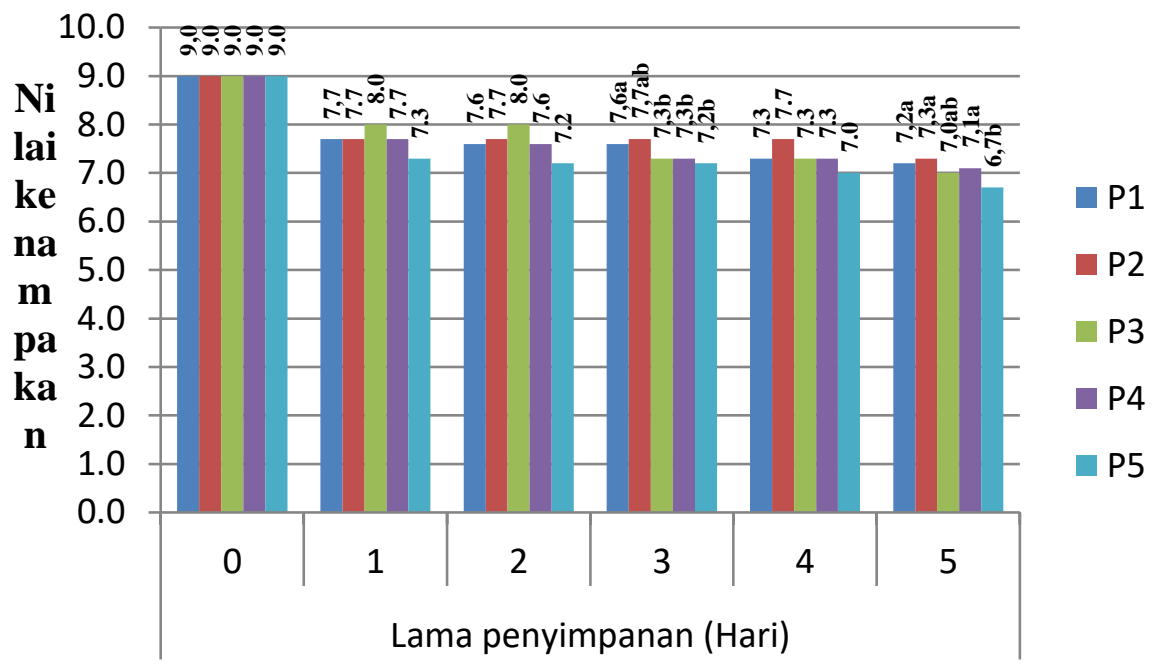

Gambar 3. Nilai kenampakan udang api-api selama penyimpanan dingin (5C)

Keterangan:

Angka dengan superscript sama dalam satu lajur menunjukkan tidak berbeda nyata

$\mathrm{P} 1=$ Ekstrak air laut + S. alba $800 \mathrm{ppm}$

$\mathrm{P} 2=$ Ekstrak air laut + S. alba $1200 \mathrm{ppm}$

P3= Ekstrak air tawar + S. alba $800 \mathrm{ppm}$

$\mathrm{P} 4=$ Ekstrak air tawar + S. alba $1200 \mathrm{ppm}$

$\mathrm{P} 5=$ Kontrol

Berdasarkan hasil analisis Kruskall Wallis menunjukkan bahwa perlakuan yang diberikan berpengaruh nyata $(P<0,05)$ terhadap kenampakan udang selama penyimpanan dingin suhu $5^{\circ} \mathrm{C}$ sehingga dilakukan uji lanjut untuk mengetahui perbedaan antar perlakuan. Hasil uji Duncan menunjukkan bahwa penyimpanan hari ke-1, 2 dan 4 tidak memperlihatkan adanya perbedaan antar perlakuan. Penyimpanan hari ke-3 menunjukkan bahwa perlakuan P1 tidak berbeda nyata dengan P2 tetapi berbeda nyata dengan P3, P4 dan P5. Perlakuan P2 tidak berbeda nyata dengan P3, P4 dan P5. Penyimpanan hari ke-5 menunjukkan bahwa perlakuan P1 tidak berbeda nyata dengan P2, P3 dan P4 tetapi berbeda dengan P5. Selanjutnya perlakuan P3 tidak berbeda nyata dengan $\mathrm{P} 5$.

41 Pengaruh Ekstrak Daun Pedada (Sonneratia Alba) Terhadap Mutu Pasca Panen Udang Api-Api (Metapenaeus Monoceros)/ Samsu Rizal, Andi Noor Asiki, Gina Saptiani

Journal of Agritechnology and Food Processing

Volume 1, No. 1, 2021

Jl. K. H. Ahmad Dahlan No. 1, Pagesangan-Mataram, Indonesia 
Nilai organoleptik udang api-api selama penyimpaan dingin $5^{\circ} \mathrm{C}$ untuk spesifikasi kenampakan terjadi penurunan dari hari ke-1 sampai ke-5. Nilai kenampakan untuk udang yang direndam dalam ekstrak daun $S$. alba dengan konsentrasi yang berbeda masih lebih tinggi dibandingkan dengan udang yang direndam tanpa menggunakan ekstrak. Pengamatan secara keseluruhan menunjukkan bahwa perendaman udang dengan menggunakan ekstrak daun $S$. alba dapat mempertahankan nilai kenampakan udang selama penyimpanan. Hasil penelitian ini sejalan dengan hasil penelitian Saptiani et al. (2018) bahwa ekstrak air laut lebih efektif dalam menghambat mikroba patogen dibanding dengan ekstrak yang menggunakan pelarut air tawar. Hal ini disebabkan karena air laut mengandung garam yang merupakan pengawet makanan alami.

Penurunan nilai kenampakan pada udang yang direndam tanpa menggunakan ekstrak pada penyimpanan hari ke-5 dengan nilai 6,7 ditunjukkan dengan tingkat kebeningan agak hilang, sedikit kusam, dan antar ruas kurang kokoh. Sedangkan udang api-api yang direndam dalam ekstrak daun pedada (S. alba) memiliki nilai organoleptik kenampakan berkisar 7,0-7,3 yang sesuai dengan standar SNI 01-2346-2006 (BSN, 2006). Dengan demikian, udang yang direndam menggunakan ekstrak daun pedada ( $\mathrm{S}$. alba) selama penyimpanan dingin $\left(5^{\circ} \mathrm{C}\right)$ telah memenuhi syarat SNI, sedangkan udang yang direndam tanpa menggunakan ekstrak tidak memenuhi standar karena nilai organoleptik kenampakannya di bawah 7,0.

\section{2) Bau}

Nilai bau udang api-api selama penyimpanan dingin $5^{\circ} \mathrm{C}$ dapat dilihat pada Gambar 4.

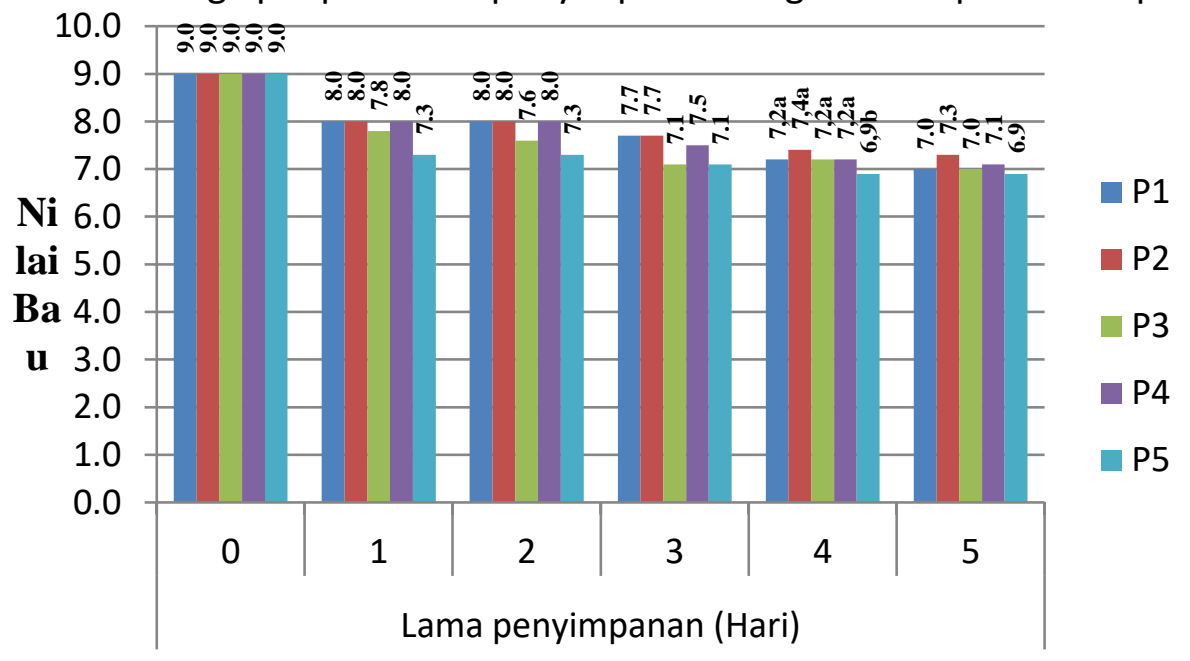

Keterangan:

Gambar 4. Nilai bau udang api-api selama penyimpanan dingin (5C)

Angka dengan superscript sama dalam satu lajur menunjukkan tidak berbeda nyata

$\mathrm{P} 1=$ Ekstrak air laut + S. alba $800 \mathrm{ppm}$

P2= Ekstrak air laut + S. alba 1200 ppm

P4= Ekstrak air tawar + S. alba 1200 ppm

P3= Ekstrak air tawar + S. alba 800 ppm

42 Pengaruh Ekstrak Daun Pedada (Sonneratia Alba) Terhadap Mutu Pasca Panen Udang Api-Api (Metapenaeus Monoceros)/ Samsu Rizal, Andi Noor Asiki, Gina Saptiani

Journal of Agritechnology and Food Processing

Volume 1, No. 1, 2021

J1. K. H. Ahmad Dahlan No. 1, Pagesangan-Mataram, Indonesia 
Berdasarkan hasil analisis Kruskall Wallis menunjukkan bahwa perlakuan yang diberikan berpengaruh nyata $(\mathrm{P}<0,05)$ terhadap bau udang selama penyimpanan dingin suhu $5^{\circ} \mathrm{C}$. Hasil uji lanjut Duncan menunjukkan bahwa penyimpanan hari ke-1, 2, 3 dan hari ke-5 dari setiap perlakuan tidak memperlihatkan adanya perbedaan, sedangkan penyimpanan hari ke-4 menunjukkan perlakuan P1, P2, P3 dan P4 tidak berbeda nyata kecuali pada perlakuan P5 yang berbeda nyata. Selama pengamatan bau udang pengalami perubahan dari yang berbau sangat segar hingga berbau spesifik dan netral hal ini menandakan bahwa udang telah mengalami penurunan mutu. Menurut Oyelese (2006), aktivitas bakteri pembusuk dalam mendekomposisi protein dan lemak menghasilkan senyawa yang tidak diinginkan seperti amoniak, indol dan $\mathrm{H}_{2} \mathrm{~S}$ yang menyebabkan bau tidak sedap. Selama penyimpanan P2 (ekstrak air laut + S. alba 1200 ppm) merupakan perlakuan yang memperlihatkan nilai bau paling tinggi yaitu 7,3 dibandingkan dengan perlakuan yang lain. Penggunaan ekstrak daun $S$. alba penyimpanan dingin $\left(5^{\circ} \mathrm{C}\right)$ diduga dapat memperlambat terjadinya proses oksidasi sehingga mampu mempertahankan bau khas udang. Nilai organoleptik bau udang selama penyimpanan dingin berkisar 7,0-7,3 yang menunjukkan masih memenuhi standar SNI, yaitu pada nilai 7 (BSN, 2006).

\section{3) Tekstur}

Nilai tekstur udang api-api selama penyimpanan dingin $\left(5^{\circ} \mathrm{C}\right)$ dapat dilihat pada Gambar 5.

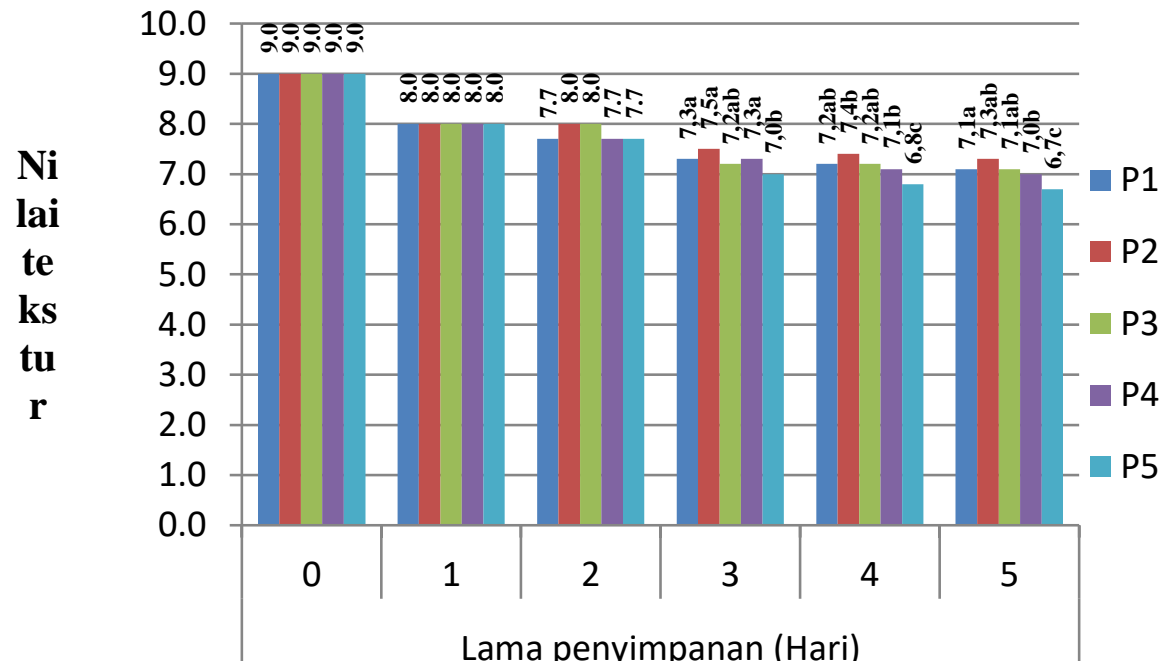

Keterangan:

Gambar 5. Nilai tekstur udang api-api selama penyimpanan dingin $(5 \circ \mathrm{C})$

Angka dengan superscript sama dalam satu lajur menunjukkan tidak berbeda nyata

$\mathrm{P} 1=$ Ekstrak air laut + S. alba $800 \mathrm{ppm}$

P4= Ekstrak air tawar + S. alba 1200 ppm

$\mathrm{P} 2=$ Ekstrak air laut + S. alba $1200 \mathrm{ppm}$ $\mathrm{P} 5=$ Kontrol

P3= Ekstrak air tawar + S. alba 800 ppm

43 Pengaruh Ekstrak Daun Pedada (Sonneratia Alba) Terhadap Mutu Pasca Panen Udang Api-Api (Metapenaeus Monoceros)/ Samsu Rizal, Andi Noor Asiki, Gina Saptiani

Journal of Agritechnology and Food Processing

Volume 1, No. 1, 2021

Jl. K. H. Ahmad Dahlan No. 1, Pagesangan-Mataram, Indonesia 
Berdasarkan hasil analisis Kruskall Wallis menunjukkan bahwa perlakuan yang diberikan berpengaruh nyata $(\mathrm{P}<0,05)$ terhadap tekstur udang selama penyimpanan dingin suhu $5^{\circ} \mathrm{C}$. Hasil uji lanjut Duncan menunjukkan bahwa penyimpanan pada hari ke-1 dan 2 setiap perlakuan tidak berbeda nyata. Penyimpanan hari ke-3 perlakuan P1 tidak berbeda nyata dengan perlakuan yang lain kecuali terhadap perlakuan P5 dan P3 tidak berbeda nyata dengan P5. Penyimpanan hari ke-4 menunjukkan bahwa P1, P2, P3 dan P4 tidak berbeda nyata kecuali terhadap P5 yang berbeda nyata. Penyimpanan hari ke-5 menunjukkan bahwa P1 tidak berbeda nyata dengan P2 dan P3 tetapi berbeda nyata dengan P4 dan P5, pada perlakuan P2 tidak berbeda nyata dengan P3 dan P4 tetapi berbeda nyata dengan P5. Nilai tekstur udang api-api mengalami penurunan seiring dengan lama waktu penyimpanan. Perlakuan tanpa perendaman dalam ekstrak mengalami penurunan nilai tekstur lebih cepat dibandingkan dengan perendaman dalam ekstrak daun S. alba. Menurut Rifka et al. (2018), penurunan nilai organoleptik tekstur karena adanya proses perombakan protein menjadi senyawa bebas oleh mikroba pengurai. Penambahan bahan alami anti bakteri dari ekstrak daun S. alba pada penyimpanan dingin $\left(5^{\circ} \mathrm{C}\right)$ diduga dapat menekan laju pertumbuhan bakteri sehingga berpengaruh terhadap tekstur udang. Hal ini sejalan dengan penelitian Pariansyah et al. (2018)bahwa ekstrak daun S. alba mengandung senyawa bioaktif yang mampu berperan sebagai antibakteri. Menurut Vakili dan Ardakani (2018) perlakuan perendaman udang pada ekstrak kulit jeruk dan udang disimpan selama 12 hari pada suhu $1-4^{\circ} \mathrm{C}$, selain dapat menghambat melanosis, ekstrak juga dapat mempertahankan tekstur.

Nilai organoleptik tekstur udang api-api dengan perendaman dalam ekstrak daun S. alba selama penyimpanan dingin berkisar 7,0-8,0 yang menunjukkan memenuhi standar SNI, yaitu dengan nilai 7 (BSN, 2006).

\section{SIMPULAN}

Perendaman udang api-api dalam ekstrak daun pedada tidak memberikan pengaruh terhadap nilai TPC dan pH selama penyimpanan dingin, namun berpengaruh terhadap uji organoleptik spesifikasi kenampakan, bau dan tekstur udang. Ekstrak daun pedada dengan pelarut air laut $1200 \mathrm{ppm}$ selama penyimpanan dingin $\left(5^{\circ} \mathrm{C}\right)$ memperoleh hasil terbaik dengan nilai TPC yaitu 2,88 log cfu/g, nilai pH 7,12 dan nilai organoleptik (kenampakan 7,3, bau 7,3 dan tekstur 7,3).

\section{DAFTAR PUSTAKA}

[BSN] Badan Standarisasi Nasional. Standar Nasional Indonesia 01-2346-2006. Petunjuk Pengujian Organoleptik dan atau Sensori Udang Segar. Badan Standarisasi Nasional. Jakarta.

Anggraini R.R, M. Hendri, dan Rozirwan. 2018. Potensi larutan bubuk daun mangrove Bruguiera gymnorrhiza sebagai pengawet alami. Maspari journal. 10(1):51-62.

44 Pengaruh Ekstrak Daun Pedada (Sonneratia Alba) Terhadap Mutu Pasca Panen Udang Api-Api

(Metapenaeus Monoceros)/ Samsu Rizal, Andi Noor Asiki, Gina Saptiani

Journal of Agritechnology and Food Processing

Volume 1, No. 1, 2021

Jl. K. H. Ahmad Dahlan No. 1, Pagesangan-Mataram, Indonesia 
Kusumadewi T, Khotimah S, Yanti A. 2014. Ekstrak Metanol Buah Sonneratia alba J.E.Sm sebagai Penghambat Pertumbuhan Helminthosporium sp yang diisolasi dari Daun Jagung. Jurnal Protobiont. 3(2):149-154.

Munandar A, Nurjanah, Nurilmala M. 2009. Kemunduran Mutu Ikan Nila (Oreochromis niloticus) pada Penyimpanan Suhu Rendah dengan Perlakuan Cara Kematian dan Penyiangan. Departemen Perikanan Universitas Sultan Ageng Tirtayasa. Departemen Teknologi Hasil Perairan Institut Pertanian Bogor.

Naiborhu. 2002. Ekstraksi dan Manfaat Ekstrak Mangrove (Sonneratia alba dan Sonneratia caseolaris) Sebagai Bahan Alami Antibakteri pada Patogen Udang Windu, Vibrio sp. Prosiding Seminar Nasional VI Ekosistem Mangrove. Pekanbaru (15-18 September 1998). 14 hal.

Ngginak J, Haryono S, dan Ferdy S. 2013. Komponen Senyawa Aktif pada Udang Putih Serta Aplikasinya dalam Pangan. Jurnal Sains Medika. 5(2):128-145.

Oyolese A.O. 2006. Quality assesment of cold smoked hot smoked and oven dried tilapia nilotica under cold storage temperature conditions. J. of Fish. Int. 2 (4):92-97.

Pariansyah A., Herliany N.E. dan Negara B.F.S.P. 2018. Aplikasi maserat buah mangrove Avicennia marinasebagaipengawet alami ikan nila segar.Acta Aquatica: Aquatic Sciences Journal. 5(1):36-44.

Riyanto R, Kusmarwati A, Dwiyitno. 2006. Pembentukan formaldehida pada ikan kerapu (Epinephelus fuscoguttatus) selama penyimpanan pada suhu kamar. Jurnal Pascapanen dan Bioteknologi Kelautan dan Perikanan. I(2): 111-116.

Salosa, Yenni Y. 2013. Uji kadar formalin, Kadar Garam dan Total Bakteri Ikan Asin Tenggiri Asal Kabupaten Sarmi Provinsi Papua. Universitas Negeri Papua, Papua.

Santi S, Saptiani G dan Catur AF. 2017. Ekstrak Daun Avicennia marina untuk Menghambat Virbrio Harveyi pada Benur Udang Windu (Peneaus monodon). Fakultas Perikanan Dan Ilmu Kelautan Universitas Mulawarman. Jurnal Veteriner Mulawarman. 23(1).

Saptiani G, AN Asikin, Fikri A, and EH Hardi. 2018. Mangrove Plants Species From Delta Mahakam, Indonesia With Antimikrobial Potency. Biodiversitas. 19(2):516-521.

Saptiani G, AN Asikin, Fikri A, and EH Hardi. 2018. Mangrove Plants Species From Delta Mahakam, Indonesia With Antimikrobial Potency. Biodiversitas. 19(2):516-521.

Sipayung B., W. Ma'ruf, dan E. Dewi. 2015. Pengaruh senyawa bioaktif buah mangrove (Avicennia marina) terhadap tingkat oksidasi fillet ikan nila merah (O. niloticus) selama penyimpanan dingin. Jurnal Pengolahan dan Bioteknologi Hasil Perikanan. 4(2).115-123.

Susanto E., Tri W. Agustini., Fronthea Swastawati., Titi Surti., Akhmad S. Fahmi., Mahmud F. Albar., dan Muhammad K. Nafi s. 2011. Pemanfaatan bahan alami untuk memperpanjang umur simpan ikan kembung (Rastrelliger neglectus). 60 Jurnal Perikanan (J. Fish. Sci.) XIII (2): 60-69 ISSN: 0853-6384.

Suwetja IK. 2011. Biokimia Hasil Perikanan. Media Prima Aksara. Jakarta (ID). 